\title{
Peningkatan Kesehatan Masyarakat di Masa Pandemi Bagi Warga Panti Asuhan di Surabaya
}

\author{
Clarashinta Canggih*1, Khusnul Fikriyah², Rachma Indrarini ${ }^{3}$, Sri Abidah Suryaningsih", Nurul \\ Hanifa $^{5}$ \\ 1,2,3,4Program Studi Ekonomi Islam, Fakultas Ekonomi, Universitas Negeri Surabaya \\ 5Program Studi Ekonomi, Fakultas Ekonomi, Universitas Negeri Surabaya \\ *e-mail: clarashintacanggih@unesa.ac.id ${ }^{1}$
}

\begin{abstract}
This Community Service Activities (PKM) is based on the condition of orphanages with many residents and nearby the centre of the crowd. Maintaining health becomes very important when living and interacting with many people during the Covid-19 pandemic. One of the efforts to maintain health is applying personal hygiene not to carry the virus to others. Based on the advice of WHO and also the Surabaya City Government, residents are asked to implement clean and healthy living behaviour (PHBS). This activity aims to improve the public's health, especially the residents of orphanages, through socialization about PHBS. Socialization is done by giving posters. Measurement of community understanding is done through the distribution of questionnaires before and after socialization. This activity shows an increase in the knowledge of the orphanage residents for clean and healthy living behaviour. In addition, the participants appeal to implement PHBS in everyday life. In the long term, the orphanage residents are more concerned with personal hygiene and apply PHBS in daily life so that it can break the chain of transmission of Covid 19.
\end{abstract}

Keywords: Clean and Healthy Life Behaviour, Covid-19 Pandemic, orphanage residents

\begin{abstract}
Abstrak
Kegiatan Pengabdian Kepada Masyarakat (PKM) ini berbasis pada kondisi panti asuhan yang dihuni oleh banyak orang dan berada di dekat pusat keramaian. Menjaga kesehatan menjadi sangat penting saat tinggal dan berinteraksi dengan banyak orang pada masa pandemi Covid-19. Salah satu upaya menjaga kesehatan dengan menerapkan kebersihan diri agar tidak menjadi pembawa virus untuk orang lain. Berdasarkan anjuran WHO dan juga Pemerintah Kota Surabaya warga diminta untuk menerapkan Perilaku Hidup bersih dan Sehat (PHBS). Kegiatan ini bertujuan untuk meningkatkan kesehatan masyarakat, terutama warga panti asuhan, melalui sosialisasi tentang PHBS. Sosialisasi dilaksanakan dengan memberikan poster. Pengukuran pemahaman masyarakat dilakukan melalui pembagian kuesioner sebelum dan setelah sosialiasi. Hasil pelaksanaan kegiatan ini, menunjukkan adanya peningkatan pemahaman warga panti akan perilaku hidup bersih dan sehat. Selain itu, warga panti memiliki keinginan untuk mengimplementasikan PHBS dalam kehidupan sehari-hari. Diharapkan pada jangka panjang warga panti lebih peduli dengan kebersihan diri dan juga menerapkan PHBS dalam keseharian sehingga dapat memutus mata rantai penularan Covid 19.
\end{abstract}

Kata kunci: Perilaku hidup bersih dan sehat, Pandemi Covid-19, warga panti asuhan

\section{PENDAHULUAN}

Di awal tahun 2020, dunia digemparkan dengan adanya laporan kasus terjangkit dan juga kematian akibat persebaran Novel Coronavirus (COVID-19) yang bermula dari Kota Wuhan, Provinsi Hubei, China dan terus menyebar ke seluruh dunia. WHO telah menetapkan COVID-19 sebagai Public Health Emergency of International Concern (PHEIC)/Kedaruratan Kesehatan Masyarakat Yang Meresahkan Dunia (KKMMD). Jumlah kasus COVID-19 jauh lebih banyak dan juga memiliki penyebaran yang lebih luas dan cepat ke beberapa negara dibanding SARS. Dari awal kemunculannya di akhir tahun 2019 hingga 4 Februari 2021, penyakit ini telah menginfeksi $103,989,900$ orang dan menyebabkan kematian 2,260,259 orang di seluruh dunia (WHO, n.d.).

Di Indonesia, kasus Covid-19 pertama kali dipublikasikan pada Maret 2020 dengan cluster Jakarta yang dengan cepat menyebar, menjadikan Jakarta sebagai epicentrum penyebaran Coronavirus di Indonesia. Untuk saat ini, bukan hanya Jakarta yang menjadi wilayah Zona Merah di Indonesia. Berdasarkan data per 21 Mei 2020, Jawa Timur menjadi provinsi dengan tingkat 
pertambahan orang terkonfirmasi positif Coronavirus terbesar, dengan penambahan pasien positif COVID sebanyak 502 kasus (Riana \& Persada, 2020). Wilayah Jawa Timur yang paling banyak terdampak adalah Surabaya. Data dari pemerintah kota Surabaya per tanggal 21 Mei 2020 secara kumulatif terdapat 1566 pasien yang terkonfirmasi positif COVID-19, peningkatan sebesar 311, dengan 1255 PDP dalam pengawasan, 468 ODP dipantau, dan kumulatif 155 positif COVID19 terkonfirmasi meninggal (Surabaya, 2020). Sedangkan di wilayah Kecamatan Jambangan terkonfirmasi 16 positif, 11 PDP, dan 9 ODP (Surabaya, 2020). Di Indonesia, COVID-19 dikategorikan sebagai bencana nasional. Presiden, melalui Kepres Nomor 12 tahun 2020, menyatakan penyebaran COVID-19 adalah bencana non-alam yang harus segera ditanggulangi (Arifin, 2020).

COVID-19 merupakan penyakit akibat infeksi Virus Severe Acute Respiratory Syndrome Coronavirus 2 (SARS-COV-2) atau novel coronavirus (2019-nCoV) (Singhal, 2020). SARS-COV-2 memiliki kemampuan bertahan hidup, berkembang biak dan menyebabkan penyakit yang tinggi, persebarannya bisa mencapai dua kali lipat dalam satu minggu dan ditularkan melalui kontak fisik erat dengan penderita melalui sentuhan wajah, mulut, hidung maupun jabat tangan (Chan et al., 2020; Singhal, 2020). Penciri dari infeksi virus ini dapat dilihat dengan kondisi pasien yang mengalami demam tinggi, kesulitan untuk bernafas, batuk kering dan juga pneumonia yang dapat menyebabkan kematian (Huang et al., 2020; Zhu et al., 2020).

Anak-anak termasuk ke dalam kelompok usia yang sangat rentan terhadap penularan COVID-19. Seringkali infeksi pada anak-anak tidak mudah terdeteksi karena sebagian dari anak yang terinfeksi tidak menunjukkan gejala. (Zimmermann \& Curtis, 2020). Namun demikian, infeksi yang terjadi pada anak-anak dalam beberapa kasus menunjukkan gejala klinis yang serupa dengan yang dialami oleh orang dewasa dan dapat berujung pada kematian (Chen et al., 2020). Sehingga penyebaran virus pada anak-anak perlu diwaspadai karena anak-anak cenderung sering berinteraksi erat dengan orang lain.

Lembaga Kesejahteraan Sosial Anak (d/h Panti Asuhan) merupakan lembaga di bidang kesejahteraan sosial yang melaksanakan fungsi Pengasuhan Anak baik milik pemerintah pusat, pemerintah daerah, maupun milik masyarakat (Peraturan Menteri Sosial Republik Indonesia Nomor 77/Huk/2011, 2011; Peraturan Menteri Sosial Republik Indonesia Nomor 1 Tahun 2020, 2020). Secara umum Panti Asuhan merupakan tempat tinggal bagi anak-anak yatim piatu, dhuafa, maupun anak yang sengaja dititipkan karena orang tua mengalami keterbatasan sehingga tidak mampu membiayai kehidupan keluarganya. Karena merupakan tempat tinggal bersama-sama, hal ini membuat kebersihan asrama yatim piatu harus menjadi perhatian khusus. Panti asuhan menjadi tempat tinggal sekaligus tempat anak yatim mengaji. Hampir 24 jam setiap harinya, dimana anak yatim menjalankan kegiatan sehari-hari, mulai tidur, makan, mandi, dan mengaji dan semua kegiatan dilakukan pada satu lokasi. Semenjak diterapkan PSBB, dimana segala kegiatan termasuk pendidikan dilakukan dari rumah, physical distancing menjadi hal yang nyaris tidak mungkin dapat diterapkan di lingkungan panti asuhan. Karena tempat yang terbatas, sehingga hampir semua hal harus dilakukan bersama dan dengan kondisi serba terbatas. Lebih lanjut (Agusty et al., 2015) menjelaskan bahwa kehidupan bersama-sama di panti asuhan dapat menimbulkan risiko kesehatan pada personal hygine penghuninya jika tidak diperhatikan dengan baik. Banyaknya penghuni yang tinggal dalam satu lokasi juga menjadi salah satu Covid-19 hotspot (Logar, 2020)

Pada Panti Asuhan Al-Hasan dan Al-Muslim Surabaya, berdasarkan info dari pengelola dan hasil observasi, penerapan kebersihan sudah dijaga. Panti Asuhan juga menerapkan peraturan-peraturan terkait kebersihan yang harus dipatuhi setiap anak yang tinggal disitu. Jika melanggar mereka juga harus menjalankan hukuman tertentu sebagai sanksinya. Lingkungan tinggal para anak yatim pun bersih dan nyaman. Namun, munculnya kasus positif Covid-19 di lingkungan Karah, maka penting bagi lingkungan Panti Asuhan untuk lebih menjaga kebersihan dan menerapkan prosedur WHO untuk menjaga diri dan lingkungan dari penyebaran virus Covid19 ini. Selain itu lokasi Panti Asuhan Al-Hasan yang berdekatan dengan keramaian yakni Pasar Karah dimana ini pasar ini merupakan tempat keramaian yang berpotensi menjadi tempat 
penyebaran virus Covid-19. Meskipun manajemen pasar Karah sudah membatasi jam operasional pasar yang hanya buka mulai pukul 06.00 sd 09.00, namun tetap saja perlu dilakukan tindakan preventif untuk mencegah terjadinya penularan kepada anak yatim panti asuhan.

Karena sifat dari SARS-COV-2 yang mudah berkembang biak dan infeksius, dan sejauh ini belum ditemukan obat yang efektif untuk penyembuhan, perlu dilakukan pencegahan dan pengendalian terhadap penyakit ini, terutama bagi warga panti asuhan. Kebersihan diri perlu dijaga dan dilakukan dengan benar, diantaranya dengan mencuci tangan secara teratur dengan sabun dan air mengalur dan menjaga etika batuk dan bersin dengan menutup mulut dan hidung saat batuk dan bersin (Chan et al., 2020).

Berdasarkan permasalahan mitra yang dianalisis, solusi yang ditawarkan dalam program ini adalah melakukan upaya peningkatan kesehatan masyarakat panti asuhan. Adapun upaya peningkatan kesehatan masyarakat ini dilakukan untuk meminimalisir penularan COVID-19 di lingkungan panti asuhan serta menjamin kebutuhan hidup anak-anak dan para penghuni panti asuhan. Kegiatan ini dilakukan melalui edukasi Perilaku Hidup Bersih dan Sehat (PHBS) pemberian vitamin dan obat-obatan untuk menjaga kesehatan tubuh dan juga bahan makanan serta perlengkapan kebersihan diri.

Secara umum Perilaku Hidup Bersih dan Sehat dapat diartikan sebagai "sekumpulan perilaku yang dipraktikkan atas dasar kesadaran sebagai hasil pembelajaran, yang menjadikan seseorang, keluarga, kelompok atau masyarakat mampu menolong dirinya sendiri (mandiri) di bidang kesehatan dan berperan aktif dalam mewujudkan kesehatan masyarakat"(Peraturan Menteri Kesehatan Republik Indonesia Nomor 2269 Tahun 2011,2011). Pada tatanan rumah tangga dan institusi pendidikan, perilaku hidup bersih dan sehat dapat dilakukan dengan cara menggunakan air bersih, mencuci tangan dengan air bersih dan sabun mengonsumsi makanan dan minuman sehat, tidak meludah di sembarang (Kementerian Kesehatan Republik Indonesia, 2011). Lebih lanjut, dalam upaya pencegahan COVID-19, Razi et al., (2020) menyampaikan bahwa perilaku hidup bersih dan sehat yang bisa dilaksanakan adalah mencuci tangan yang baik dan benar, menerapkan etika batuk yang benar, menjaga jarak fisik, dan menjaga kebersihan diri. Kegiatan ini sangat penting dilaksanakan karena sebagian besar anak - anak sering lupa terkait perilaku hidup bersih.

Kegiatan Edukasi Perilaku Hidup Bersih dan Sehat pada warga Panti Asuhan Al Hasan dan Al Muslim dilakukan melalui media poster sehingga anak- anak dengan sangat mudah untuk mengingat. Poster dipilih karena merupakan salah satu bentuk media yang dapat digunakan dengan mudah untuk menyampaikan informasi. Menurut Jumilah et al., (2017), penggunaan media poster dapat meningkatkan pengetahuan anak-anak dan pemasangan poster dalam jangka waktu tertentu dapat digunakan sebagai alat promosi untuk peningkatan kesehatan. Diharapkan dengan pemberian edukasi melalui poster, pemberian vitamin dan obat-obatan untuk menjaga kesehatan tubuh dan juga bahan makanan serta perlengkapan kebersihan diri dapat meningkatkan kesadaran warga Panti Asuhan Al Hasan dan Al Muslim Surabaya untuk menjaga kebersihan dan kesehatan di masa pandemic COVID-19.

\section{METODE}

Panti Asuhan Al-Hasan dan Panti Asuhan Al-Muslim merupakan mitra pengabdian masyarakat yang terletak di Kecamatan Jambangan Surabaya. Lokasi panti yang dekat dengan keramaian dan juga penghuni panti yang padat menjadi fokus kegiatan. Kegiatan pengabdian kepada masyarakat di Panti Asuhan ini dilaksanakan dalam bentuk sosialisasi perilaku hidup bersih dan sehat di masa Pandemi bagi warga panti asuhan Al-Hasan dan Al-Muslim Surabaya yang terdiri dari:

a. Pra pelaksanaan, diawali dengan survey ke panti asuhan untuk melihat kondisi dan berkoordinasi denga ketua Yayasan panti asuhan guna mendukung kegiatan peningkatan kesehatan warga panti asuhan. 
b. Persiapan penyusunan materi dan pembuatan poster terkait PHBS

c. Pelaksanaan kegiatan peningkatan kesehatan masyarakat warga panti asuhan Al-Hasan dan Al-Muslim dengan membagikan poster PHBS, memberikan bantuan bahan pangan, vitamin dan obat-obatan, serta alat kebersihan diri

d. Monitoring dan evaluasi dimana mitra melaporkan implementasi hasil pelatihan secara singkat

Sosialiasi dilakukan untuk meningkatkan pemahaman masyarakat, penghuni panti asuhan Al Hasan dan Al Muslim, tentang Perilaku Hidup Bersih dan Sehat sebagai salah satu upaya untuk peningkatan kesehatan di masa pandemi Covid-19. Untuk mengukur pemahaman warga panti asuhan, termasuk dampak dari sosialisasi, digunakan kuesioner yang berisi pertanyaan tentang Perilaku Hidup Bersih dan Sehat. Kuesioner ini diberikan kepada penghuni panti sebelum dan setelah sosialisasi dilaksanakan. Hasil kuesioner pre dan post sosialisasi diolah dengan pendekatan kuantitatif deskriptif untuk mengukur pemahaman dan juga dampak sosialiasi terhadap pemahaman warga panti asuhan.

\section{HASIL DAN PEMBAHASAN}

\subsection{Profil Mitra}

Panti Asuhan Al-Hasan dan Al-Muslim ini ini berada di Kelurahan Karah Kecamatan Jambangan kota Surabaya Provinsi Jawa Timur dimana warga pada kedua Panti Asuhan ini mayoritasnya berjenis kelamin laki-laki dengan rata-rata berusia 11-20 tahun. Dari hasil analisis, jumlah peserta yang hadir pada kegiatan pengabdian masyarakat ini sebanyak 45 orang di Panti Al-Hasan dan Panti asuhan A-Muslim sebanyak 35 orang.

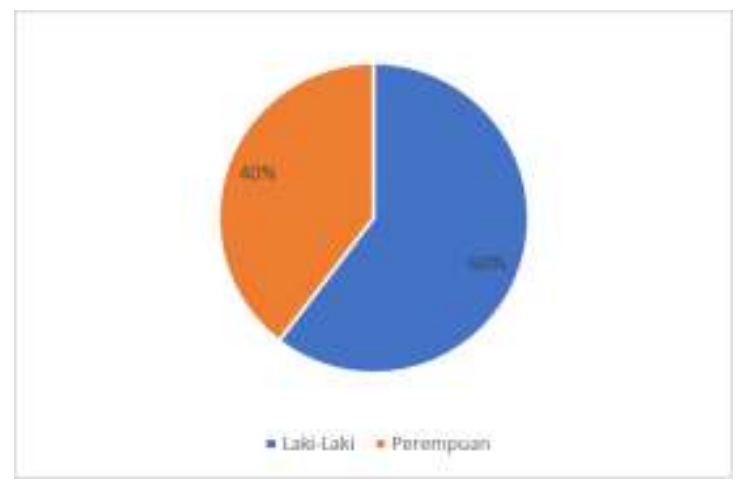

Gambar 1. Jenis Kelamin Peserta Kegiatan

Dapat dilihat dari gambar 1 bahwa mayoritas peserta sosialiasi adalah laki-laki. Hal ini dikarenakan mayoritas penghuni dan pengurus panti adalah laki-laki. Sedangkan dilihat dari sebaran umur, peserta sosialisasi rata-rata berusia 11-20 tahun, dimana penghuni panti mayoritas adalah remaja yang dijelaskan oleh gambar 2 .

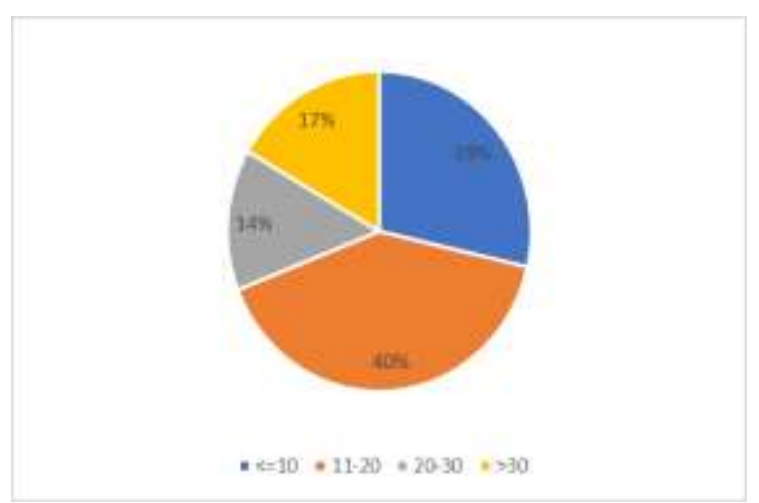

Gambar 2. Sebaran Umur Peserta 
Permasalahan mitra dalam pengabdian kepada masyarakat ini adalah lokasi panti Asuhan yang berdekatan dengan keramaian dimana pada saat ini terdapat kasus positif Covid-19 di lingkungan kelurahan tepatnya di Pasar Karah. Tempat keramaian merupakan tempat yang berpotensi menjadi tempat penyebaran virus Covid-19. Meskipun manajamen Pasar Karah sudah membatasi jam operasional pasar dengan jam buka mulai pukul 06:00 s.d 09:00 WIB, namun tetap saja perlu dilakukan Tindakan preventif untuk mencegah terjadinya penularan kepada warga panti asuhan.

\subsection{Sosialisasi Pola Hidup bersih dan Sehat (PHBS)}

Sementara itu, respon dan antusiasme peserta dalam kegiatan ini sangat besar yang tercermin dari banyaknya jumlah peserta yang hadir dalam pelaksanaan sosialisasi. Secara umum peserta sosialisasi menyatakan bahwa sosialisasi disampaikan dengan sangat jelas (44\%), seperti yang disajikan pada gambar 3.

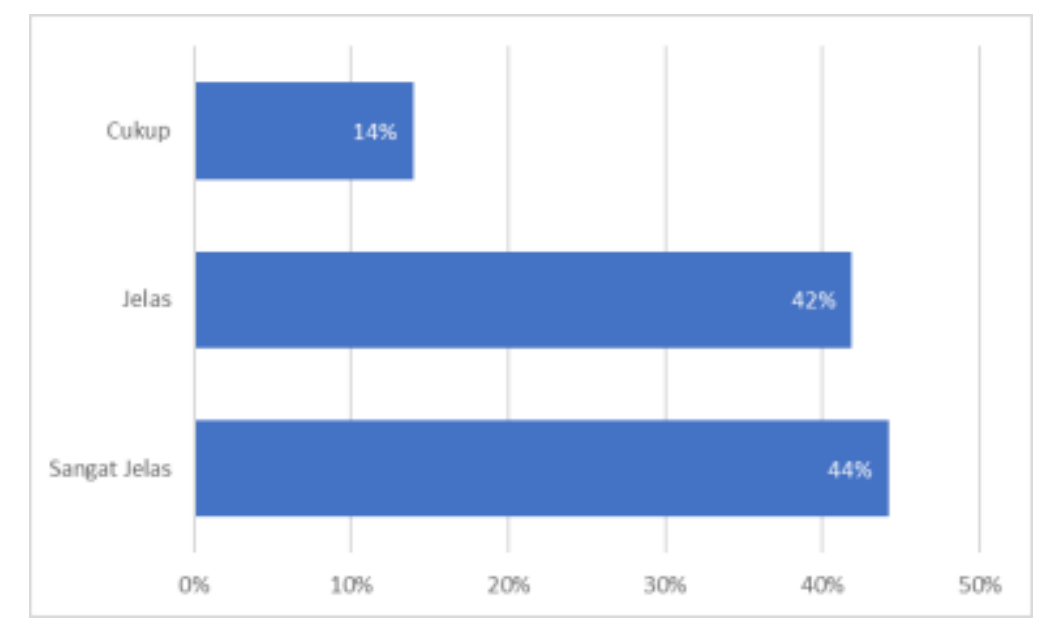

Gambar 3. Kejelasan Penyampaian Materi

Selanjutnya, penilaian peserta pelatihan tentang pentingnya materi yang disampaikan saat sosialisasi, mayoritas peserta menjawab Sangat Penting terlihat pada gambar 4 .

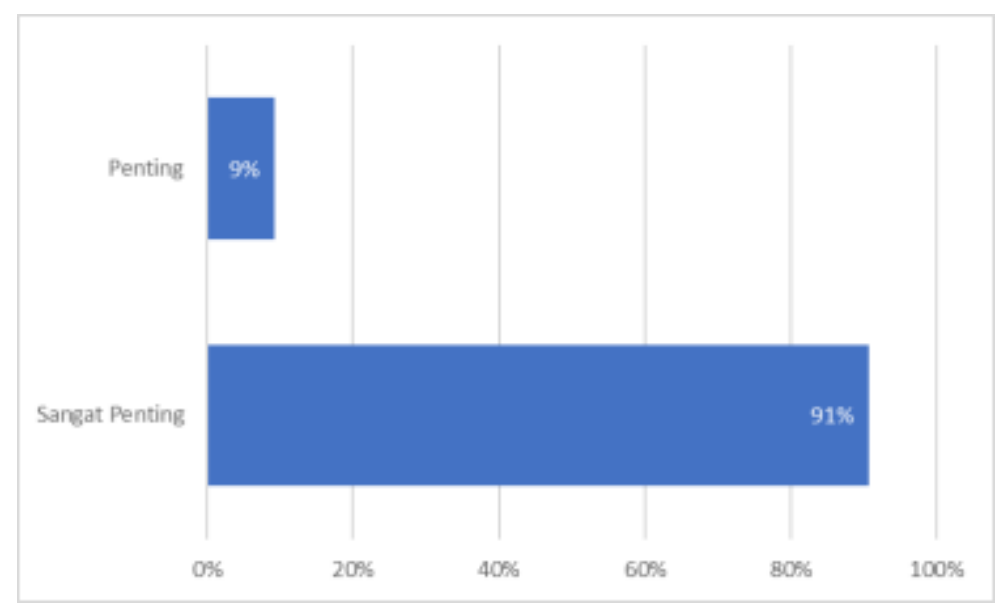

Gambar 4. Pentingnya Materi yang Disampaikan

Kegiatan Pengabdian Kepada Masyarakat dalam Peningkatan Kesehatan masyarakat ini dilaksanakan melalui sosialiasi dengan pembagian poster mengenai penerapan pola hidup bersih dan sehat sesuai dengan anjuran WHO dan pemberian bantuan vitamin, obat-obatan, alat kebersihan diri, dan bahan pangan untuk menjaga dan meningkatkan kesehatan para penghuni panti. 

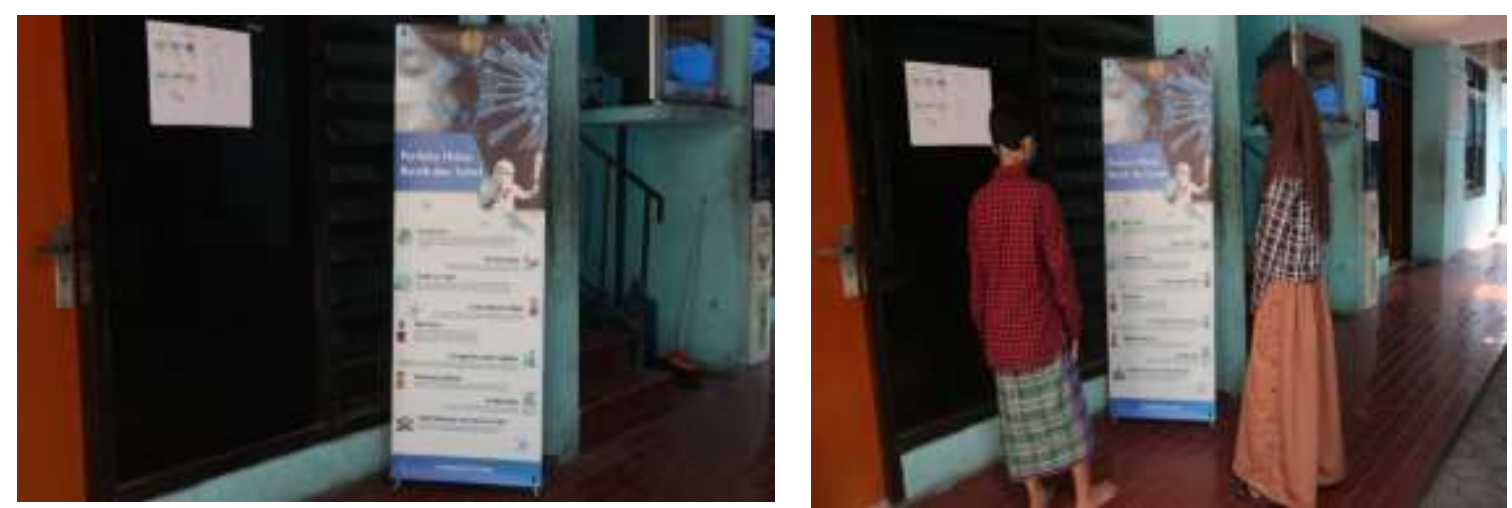

Gambar 5. Pemasangan Poster PHBS di Panti Asuhan

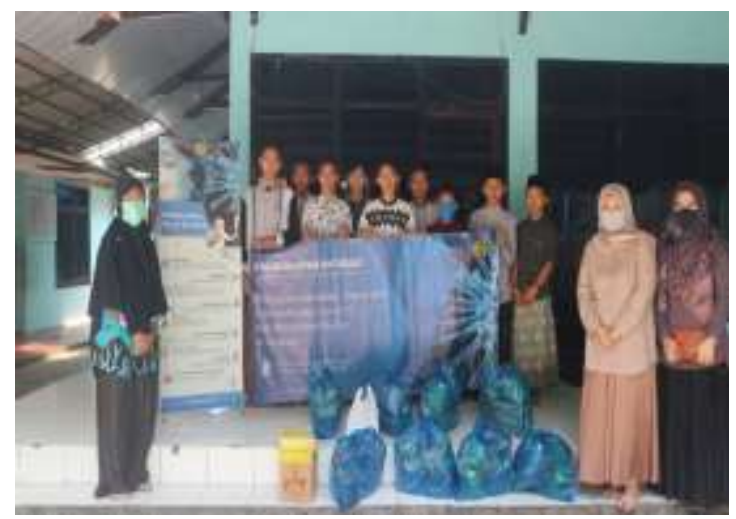

Gambar 6. Bantuan berupa Vitamin, obat-obatan, bahan pahan dan alat kebersihan diri bagi warga panti asuhan

Pemberian bantuan berupa vitamin, obat-obatan, bahan pangan dan alat kebersihan diri sebagaimana pada gambar 6 diharapkan dapat meningkatkan Kesehatan dan kesejahteraan penghuni panti asuhan.

Poster merupakan media visual yang memudahkan penyampaian pesan, terutama terkait pesan Pendidikan Kesehatan. Keberadaan gambar dan desain visual yang menarik pada poster meningkatkan minat untuk membaca informasi yang ada di dalamnya(Rahmawati et al., 2020; Ulya \& Iskandar, 2017). Penggunaan media poster pada pemberian informasi Kesehatan efektif dan berpengaruh signifikan dalam meningkatkan pengetahuan dan sikap anak dalam pencegahan penyakit infeksius (J et al., 2019; Ulya \& Iskandar, 2017). Sosialisasi melalui poster seperti pada gambar 7 diharapkan dapat memberikan informasi mengenai PHBS pada warga panti dan bisa digunakan sebagai pengingat dalam kehidupan sehari-hari. Diharapkan warga panti dapat lebih aware dengan kebersihan diri dan juga menerapkan PHBS dalam keseharian sehingga dapat memutus mataa rantai penularan Covid-19.

\subsection{Perubahan Pemahaman tentang Covid-19 dan Perilaku Hidup Bersih dan Sehat (PHBS)}

Pengukuran pemahaman tentang PHBS dilakukan melalui kuesioner yang diberikan sebelum dan setelah sosialisasi. Pre-test digunakan untuk memberikan gambaran tingkat pemahaman warga panti tentang PHBS. Sedangkan post-test digunakan untuk mengukur perubahan pemahaman setelah dilakukan sosialisasi. Hasil rekapitulasi dan perbandingan pre dan post-test disajikan pada gambar 7. 


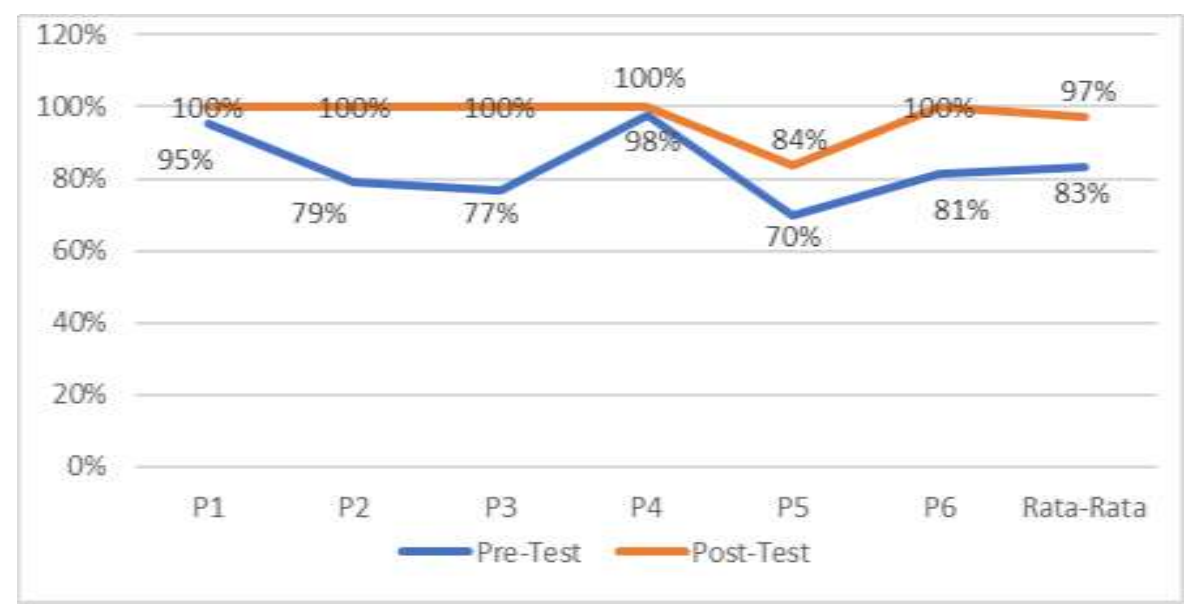

Gambar 7. Rekapitulasi Hasil Pre-test dan Post-test

Hasil pre-test dalam gambar 7 tersebut menunjukkan bahwa secara umum penghuni panti cukup memiliki pengetahuan tentang Covid-19 dan PHBS dengan rata rata hasil sebesar 83\%. Kemudian hasil post-test menunjukkan rata-rata hasil sebesar 97\%. Dapat terlihat dari gambar 10 bahwa ada peningkatan pemahaman dari penghuni panti setelah dilakukan sosialisasi. Hasil kegiatan ini selaras dengan hasil kegiatan pengabdian yang dilakukan oleh (Handayani et al., 2020; Marwang \& Sudirman, 2020; Rahmadeni et al., 2019; Suprapto, 2021; Zukmadani et al., 2020) dimana kegiatan penyuluhan dan sosialisasi yang diberikan kepada anak-anak penghuni panti asuhan dapat meningkatkan pengetahuan mereka tentang perilaku hidup bersih dan sehat. Sosialisasi ini merupakan sarana edukasi untuk mendorong perubahan perilaku kesehatan dan kehidupan masyarakat agar lebih higienis (Anhusadar \& Islamiyah, 2020; Wijayanti et al., 2017).

Pengetahuan terkait Perilaku Hidup Bersih dan Sehat sangat penting dimiliki dan diimplementasikan, khususnya pada masa pandemi covid saat ini. Dengan memiliki pengetahuan dan pemahaman yang cukup tentang Perilaku Hidup Bersih dan Sehat akan menghindarkan dari penyakit infeksius, termasuk Covid-19, yang disebabkan oleh kondisi lingkungan yang kurang bersih ataupun persebaran virus (Raksanagara \& Raksanagara, 2015; Sulaeman \& Supriadi, 2020). Beberapa kegiatan yang diterapkan dalam PHBS yakni mencuci tangan sebelum dan sesudah makan, mengkonsumsi makanan yang bergizi, menggunakan jamban yang bersih, olahraga yang teratur, memberantas jentik nyamuk, tidak merokok, membuang sampah pada tempatnya dan melakukan kerja bakti (Kementerian Kesehatan Republik Indonesia, 2011; Lensoni et al., 2020). Dengan terciptanya lingkungan yang sehat dan bersih maka anak - anak dipanti asuhan dapat terhindar dari kuman dan virus. Selain itu agar tidak terjangkit virus covid19 perlu dilakukan tambahan bentuk kegiatan 5M yakni menggunakan masker, mencuci tangan, menjaga jarak, menjauhi kerumunan dan mengurangi mobilitas sesuai dengan anjuran pemerintah.

Penerapan PHBS sendiri memerlukan komitmen dari masing-masing invidu untuk senantiasa mengimplementasikan perilaku hidup bersih dan sehat (Fatmawati et al., 2019). Berdasarkan hasil kuesioner, ditunjukkan pada gambar 8, untuk indikator keinginan untuk mengamalkan perilaku hidup bersih dan sehat seluruh peserta menjawab Ya. 


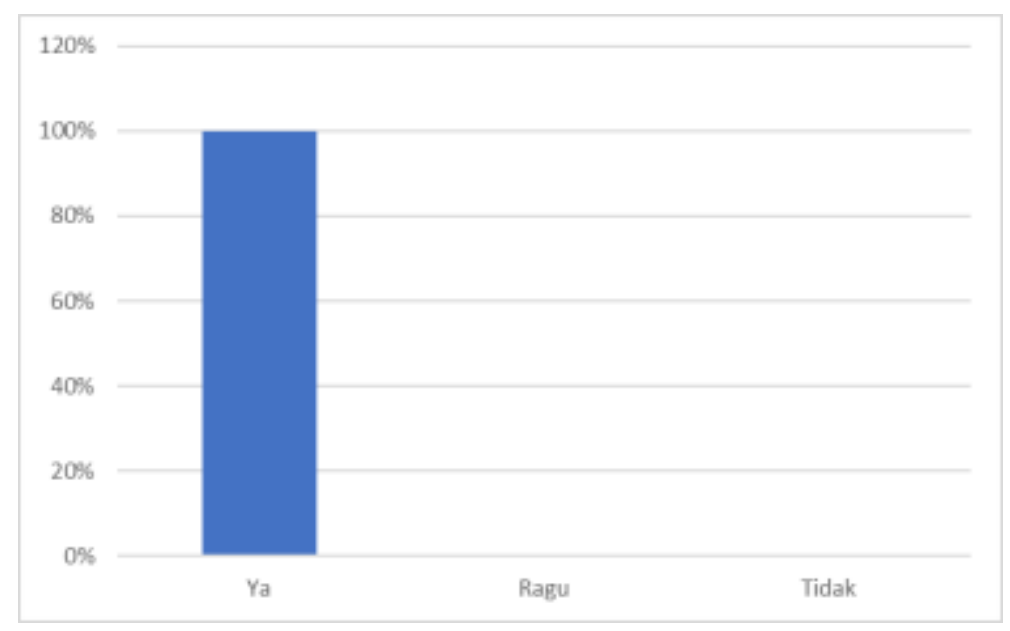

Gambar 8. Keinginan mengamalkan PHBS

Diharapkan dengan aktivitas yang dilaksanakan dapat meningkatkan komitmen warga panti dan mendorong warga panti untuk selalu melaksanakan PHBS dalam kehidupan sehariharinya sehingga menjadi lebih sehat dan terbebas dari penyakit infeksius, termasuk Covid-19.

\section{KESIMPULAN}

1. Profil Mitra merupakan warga Panti Asuhan Al-Hasan dan Al-Muslim yang terletak di Kelurahan Karah Kecamatan Jambangan kota Surabaya Provinsi Jawa Timur dimana warga pada kedua Panti Asuhan ini mayoritasnya berjenis kelamin laki-laki dengan rata-rata berusia 11-20 tahun.

2. Program sosialisasi PHBS dan pemberian vitamin, bahan makanan untuk meningkatkan kesehatan tubuh di masa pandemi Covid-19 untuk penghuni panti asuhan dilakukan untuk memotivasi para warga Panti Asuhan agar terus mengupayakan dan selalu menerapkan pola hidup bersih dan sehat dalam setiap kegiatan atau aktivitas yang dilakukan dalam sehari-hari

3. Sosialisasi PHBS dilakukan dengan media poster karena dianggap lebih efektif dan menarik dalam memberikan informasi kepada warga panti

4. Sosialisasi bertujuan agar warga panti dapat menerapkan PHBS dalam keseharian sehingga dapat memutus mata rantai penularan Covid-19.

5. Secara umum pemahaman warga panti terhadap PHBS cukup baik, dan sosialisasi dapat meningkatkan pemahaman dari penghuni panti tentang perlunya melakukan pola hidup bersih dan sehat di masa pandemi.

6. Para penghuni panti asuhan sangat mendukung jika kegiatan ini dilanjutkan di kemudian hari agar pemahaman mengenai PHBS ini semakin bermanfaat tidak hanya di lingkungan panti asuhan namun bagi masyarakat sekitar yang rentan masih belum teredukasi dengan baik terhadap hidup bersih dan sehat di masa pandemi ini.

\section{UCAPAN TERIMA KASIH}

Penulis mengucapkan terima kasih kepada Fakultas Ekonomika dan Bisnis Universitas Negeri Surabaya yang telah memberi dukungan finansial terhadap pengabdian ini.

\section{DAFTAR PUSTAKA}

Agusty, K., Chahaya, I., \& Ashar, T. (2015). Analisis Kondisi Hygiene Sanitasi Pemondokan dan Keluhan Kesehatan Kulit di Panti Asuhan Al-Jam'iyatul Washliyah Pulo Brayan Tahun 2015. 
Lingkungan Dan Keselamatan Kerja, 4(3), 1-8.

Anhusadar, L., \& Islamiyah, I. (2020). Penerapan Perilaku Hidup Bersih dan Sehat Anak Usia Dini di Tengah Pandemi Covid 19. Jurnal Obsesi : Jurnal Pendidikan Anak Usia Dini, 5(1), 463. https://doi.org/10.31004/obsesi.v5i1.555

Arifin, D. (2020). Presiden Tetapkan COVID-19 Sebagai Bencana Nasional. Tempo Nasional. https://nasional.tempo.co/read/1344931/penyebab-jumlah-pasien-covid-19-melonjak973-orang

Chan, J. F. W., Yuan, S., Kok, K. H., To, K. K. W., Chu, H., Yang, J., Xing, F., Liu, J., Yip, C. C. Y., Poon, R. W. S., Tsoi, H. W., Lo, S. K. F., Chan, K. H., Poon, V. K. M., Chan, W. M., Ip, J. D., Cai, J. P., Cheng, V. C. C., Chen, H., ... Yuen, K. Y. (2020). A familial cluster of pneumonia associated with the 2019 novel coronavirus indicating person-to-person transmission: a study of a family cluster. The Lancet, 395(10223), 514-523. https://doi.org/10.1016/S0140-6736(20)30154-9

Chen, Z. M., Fu, J. F., Shu, Q., Chen, Y. H., Hua, C. Z., Li, F. B., Lin, R., Tang, L. F., Wang, T. L., Wang, W., Wang, Y. S., Xu, W. Z., Yang, Z. H., Ye, S., Yuan, T. M., Zhang, C. M., \& Zhang, Y. Y. (2020). Diagnosis and treatment recommendations for pediatric respiratory infection caused by the 2019 novel coronavirus. World Journal of Pediatrics, 16(3), 240-246. https://doi.org/10.1007/s12519020-00345-5

Fatmawati, T. Y., Ariyanto, A., \& Nurfitriani, N. (2019). PKM Peningkatan Perilaku Hidup Sehat Pada Lanjut Usia Di Panti Sosial Tresna Werdha Kota Jambi. J-Dinamika: Jurnal Pengabdian Masyarakat, 4(1), 98-102. https://doi.org/10.25047/j-dinamika.v4i1.1055

Handayani, D., Dominica, D., \& Oktoviani. (2020). Komunikasi, Informasi, dan Edukasi Covid-19 di Panti Asuhan Bumi Rafflesia Kota Bengkulu. LOGISTA-Jurnal Ilmiah Pengabdian Kepada Masyarakat, 4(2), 256-262. https://doi.org/https://doi.org/10.25077/logista.4.2.256262.2020.

Huang, C., Wang, Y., Li, X., Ren, L., Zhao, J., Hu, Y., Zhang, L., Fan, G., Xu, J., Gu, X., Cheng, Z., Yu, T., Xia, J., Wei, Y., Wu, W., Xie, X., Yin, W., Li, H., Liu, M., ... Cao, B. (2020). Clinical features of patients infected with 2019 novel coronavirus in Wuhan, China. The Lancet, 395(10223), 497-506. https://doi.org/10.1016/S0140-6736(20)30183-5

J, H., Oktavidiati, E., \& Astuti, D. (2019). Pengaruh Pendidikan Kesehatan Media Video dan Poster Terhadap Pengetahuan dan Sikap Anak dalam Pencegahan Penyakit Diare. Jurnal Kesmas Asclepius, 1(1), 75-85. https://doi.org/https://doi.org/10.31539/jka.v1i1.747 PENGARUH

Jumilah, J., Jauhari, A. H., \& Ridha, A. (2017). Efektifitas Media Poster Terhadap Peningkatan Pengetahuan Tentang Kesehatan Gigi (Studi pada siswa-siswi kelas V SD Negeri di Kelurahan Saigon). JUMANTIK (Jurnal Mahasiswa Dan Peneliti Kesehatan), 1(02), 1-11. http://openjurnal.unmuhpnk.ac.id/index.php/JJUM/article/view/315/250

Kementerian Kesehatan Republik Indonesia. (2011). Pedoman Pembinaan Perilaku Hidup Bersih dan Sehat (PHBS). In Peraturan Menteri Kesehatan Republik Indonesia nomor: 2269/MENKES/PER/XI/2011 Pedoman pembinaan perilaku hidup bersih dan sehat (PHBS).

Peraturan Menteri Kesehatan Republik Indonesia Nomor 2269 Tahun 2011, (2011) (testimony of Kementerian Kesehatan Republik Indonesia).

Peraturan Menteri Sosial Republik Indonesia Nomor 77/Huk/2011, (2011) (testimony of Kementerian Sosial Republik Indonesia).

Peraturan Menteri Sosial Republik Indonesia Nomor 1 Tahun 2020, (2020) (testimony of Kementerian Sosial Republik Indonesia).

Lensoni, Yulinar, Rahmawati, C., Meliyana, Safitri, E., \& Rahmayani, D. (2020). Pelatihan Pencegahan Penularan Penyakit Scabies dan Peningkatan Hidup Bersih dan Sehat Bagi Santriwan. Dinamisia: Jurnal Pengabdian Kepada Masyarakat, 4(3), 470-475. https://doi.org/10.31849/dinamisia.v4i3.4519

Logar, S. (2020). Care home facilities as new COVID-19 hotspots: Lombardy Region (Italy) case study. Archives of Gerontology and Geriatrics, 89(July-August), 104087. https://doi.org/https://doi.org/10.1016/j.archger.2020.104087

Marwang, S., \& Sudirman, J. (2020). Upaya Peningkatan Pengetahuan Tentang Pencegahan Covid19 dengan Perilaku Hidup Bersih, Sehat dan Gizi Seimbang di Panti Asuhan. Jurnal Pengabdian Nasional (JPN) Indonesia, 1(2), 47-50. https://doi.org/10.35870/jpni.v1i2.15 
Rahmadeni, A. S., Hayat, N., Novia, R., Siska, D., \& Yunaspi, D. (2019). Penyuluhan Perilaku Hidup Bersih dan Sehat dan Pembagian Sembako pada Anak di Panti Asuhan Mahabbatul Haq Tanjung Uma Batam. Jurnal Abdimas Saintika, 1(1), 141-144. https://doi.org/http://dx.doi.org/10.30633/jas.v1i1.485

Rahmawati, Rahmah, S. F., Mahda, D. R., Purwati, T., Utomo, B. S., \& Nasution, A. M. (2020). Edukasi Protokol Kesehatan dalam Menjalankan New Normal di Masa Pandemik Melalui Media Poster. Seminar Nasional Pengabdian Masyarakat LPPM UMJ, 1-5. http://jurnal.umj.ac.id/index.php/semnaskat

Raksanagara, A., \& Raksanagara, A. (2015). Perilaku Hidup Bersih Dan Sehat Sebagai Determinan Kesehatan Yang Penting Pada Tatanan Rumah Tangga Di Kota Bandung. Jurnal Sistem Kesehatan, 1(1), 30-34. https://doi.org/10.24198/jsk.v1i1.10340

Razi, F., Yulianty, V., Amani, S. A., \& Fauzia, J. H. (2020). Bunga Rampai COVID-19 : Buku Kesehatan Mandiri Untuk Sahabat \#DiRUMAHAJA. In PD Prokami Kota Depok (Maret 2020).

Riana, F., \& Persada, S. (2020). Jawa Timur Catat Pasien Terbanyak Covid-19 pada 21 Mei: 502 Kasus. Tempo Nasional. https://nasional.tempo.co/read/1344945/jawa-timur-catat-pasienterbanyak-covid-19-pada-21-mei-502-kasus

Singhal, T. (2020). Review on COVID19 disease so far. The Indian Journal of Pediatrics, 87(April), 281-286.

Sulaeman, \& Supriadi. (2020). Peningkatan Pengetahuan Masyarakat Desa Jelantik Dalam Menghadapi Pandemi Corona Virus Diseases-19 (Covid-19). Jurnal Pengabdian UNDIKMA: Jurnal Hasil Pengabdian \& Pemberdayaan Kepada Masyarakat, 1(1), 12-17. http://ejournal.uncen.ac.id/index.php/JP/article/view/144

Suprapto, S. (2021). Edukasi Perilaku Hidup Bersih dan Sehat Era Pandemi COVID-19. Abdimas Singkerru, 1(1), 1-7.

Surabaya, P. K. (2020). Statistik Covid19. Surabaya Lawan COVID-19. https://lawancovid19.surabaya.go.id/visualisasi/graph

Ulya, Z., \& Iskandar, A. (2017). Pengaruh Pendidikan Kesehatan Dengan Media Poster Terhadap Pengetahuan Manajemen Hipertensi Pada Penderita Hipertensi. Jurnal Keperawatan Soedirman, 12(1), 38. https://doi.org/10.20884/1.jks.2017.12.1.715

WHO. (n.d.). WHO Coronavirus Disease (COVID-19) Dashboard. Situation by Country, Territory \& Area Name. Retrieved February 4, 2021, from https://covid19.who.int/

Wijayanti, R. A., Nuraini, N., \& Deharja, A. (2017). Efektifitas Penyuluhan Perilaku Hidup Bersih Dan Sehat (Phbs) Dalam Meningkatkan Pengetahuan Siswa Di Smp Islam Mahfilud Duror Jelbuk. Jurnal Ilmiah Inovasi, 16(3), 204-208. https://doi.org/10.25047/jii.v16i3.312

Zhu, N., Zhang, D., Wang, W., Li, X., Yang, B., Song, J., Zhao, X., Huang, B., Shi, W., Lu, R., Niu, P., Zhan, F., Ma, X., Wang, D., Xu, W., Wu, G., Gao, G. F., \& Tan, W. (2020). A Novel Coronavirus from Patients with Pneumonia in China, 2019. New England Journal of Medicine, 382(8), 727-733. https://doi.org/10.1056/nejmoa2001017

Zimmermann, P., \& Curtis, N. (2020). Coronavirus infections in children including COVID-19: An overview of the epidemiology, clinical features, diagnosis, treatment and prevention options in children. Pediatric Infectious Disease Journal, 39(5), 355-368. https://doi.org/10.1097/INF.0000000000002660

Zukmadani, A. Y., Karyadi, B., \& Kasrina. (2020). Edukasi Perilaku Hidup Bersih dan Sehat (PHBS) dalam Pencegahan COVID-19 Kepada Anak-Anak di Panti Asuhan. Jurnal Pengabdian Masyarakat, 3(1), 68-76. https://doi.org/10.29303/jpmpi.v3i1.440 